\title{
C:
}

\section{Natural History Observations of Amazon Treeboas (Corallus hortulanus) on Three Islands in the Parnaíba Delta, Brazil}

Pedro da Costa Silva ${ }^{1}$ and Robert W. Henderson ${ }^{2}$

${ }^{1}$ Núcleo de Pesquisa em Biodiversidade e Biotecnologia, BIOTEC, Universidade Federal do Piauí,

Campus Ministro Reis Vellozo, Parnaíba, Piauí. Cep: 64202-020, Brazil

${ }^{2}$ Milwaukee Public Museum, Milwaukee, Wisconsin 53233, USA (henderson@mpm.edu)

Photographs by the senior author except where indicated.

Tn June of 2010, the senior author initiated surveys of Amazon Treeboas (Corallus hortulanus, Fig. 1) along waterways of the Parnaíba Delta. Since then, he has logged 1,440 survey hours that resulted in 1,320 encounters with $C$. hortulanus.

\section{Study Area}

The Parnaíba Delta is an area of 2,700 $\mathrm{km}^{2}$, comprised of more than 70 islands and islets divided between the Brazilian states of Piauí and Maranhão. Surveys were conducted in three areas

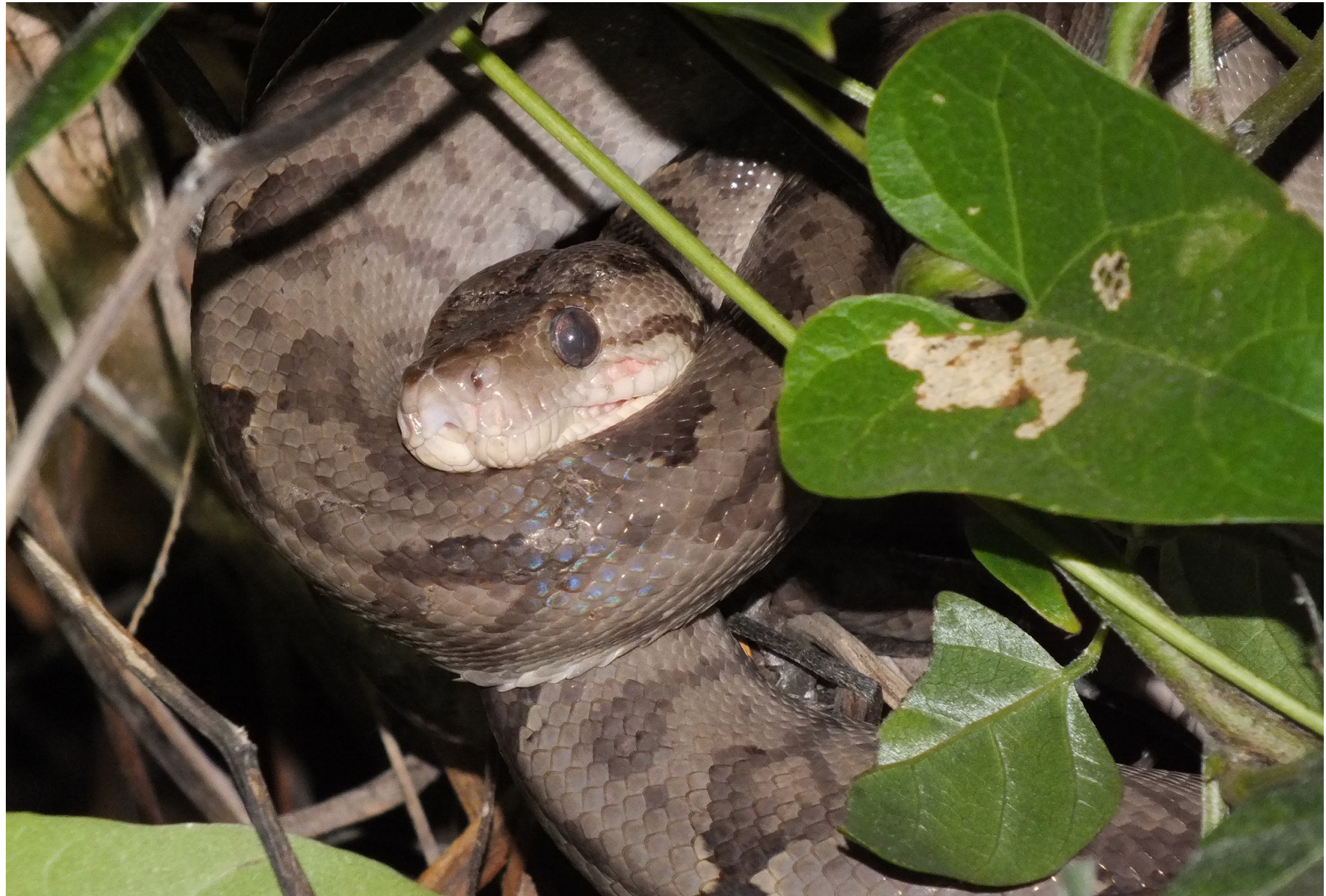

Fig. 1. An Amazon Treeboa (Corallus hortulanus) in a daytime retreat on Batatas Island in the Parnaíba Delta, Brazil. 


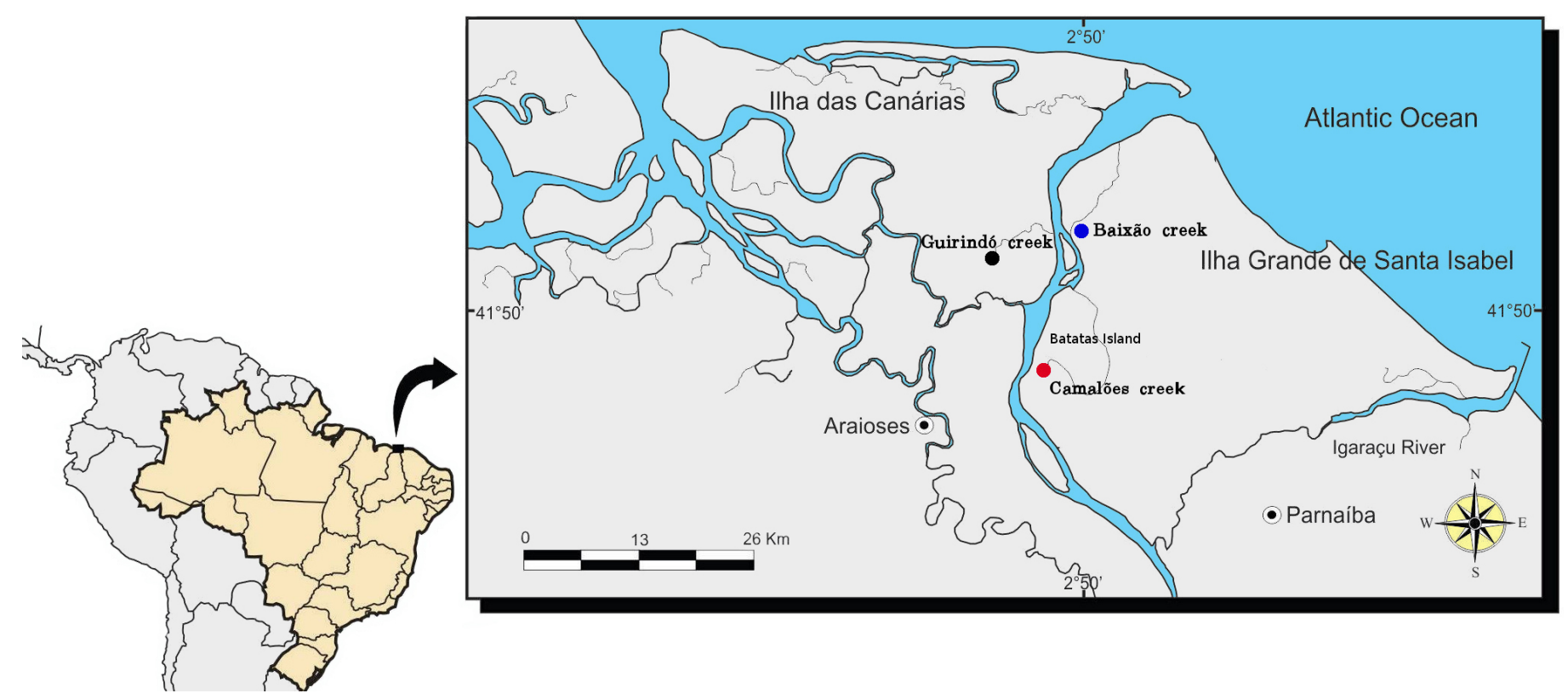

Fig. 2. Maps depicting the three islands, their creeks, and their geographic location in Brazil.

known to be used by foraging treeboas (Fig. 2): Camaleões Creek on Ilha das Batatas, Baixão Creek on Ilha Grande, and Guirindó Creek on Canárias (Fig. 3). The three islands are characterized by vegetation that occurs on wetlands adjacent to rivers and creeks and comprised mainly by an aquatic macrophyte (Montrichardia linifera), thorn-laden Machaerium lunatum, Pumpwoods (Cecropia sp.), Oil Palm (Elaeis guinesis), Java-plum (Syzygium cumini), Jenipapeiro (Jenipa americana), Inga de paca (Inga vera), Monguba (Pachira aquatic), Red Mangrove (Rhizophora mangle), and Black Mangrove (Avicennia germinans). The area also is used for agriculture, including rice (planted in the wetlands adjacent to creeks),

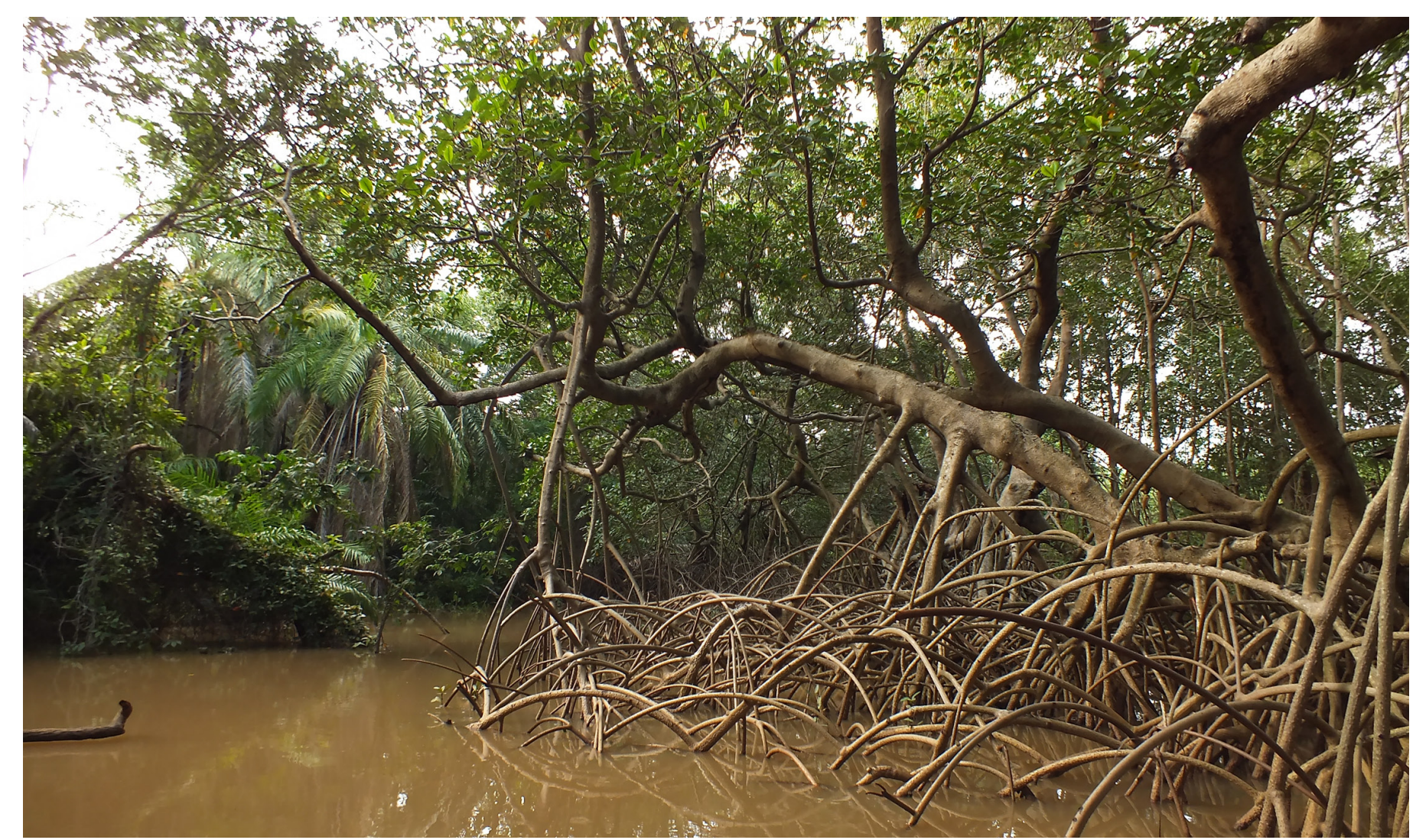

Fig. 3. Habitat along Guirindó creek. 


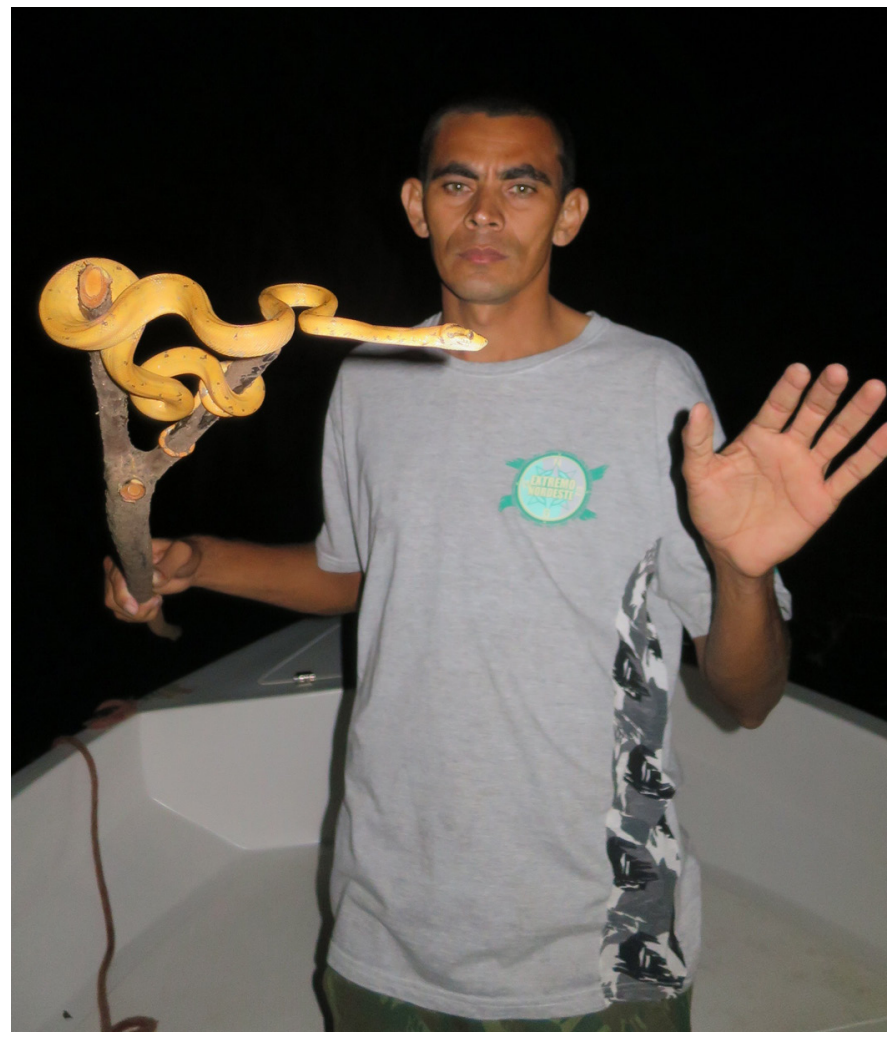

Fig. 4. The senior author with a spectacular yellow Amazon Treeboa (Corallus hortulanus). Photograph by Mr. Boiteau.

bananas, beans, and cane sugar on the uplands in the interior of the islands. Average annual rainfall exceeds $1,200 \mathrm{~mm}$, falling mainly during January to May (IBAMA, 1998).

\section{Methods}

Surveys by canoe (Fig. 4) along each creek were conducted monthly from June 2010 until April 2014. The creeks range from $1-5 \mathrm{~km}$ in length, although only $1.5 \mathrm{~km}$ were accessible by canoe. Treeboas were observed and photographed; an infrared monocular (Yukon nightfall), an LED flashlight, and a camera with night vision capability (Sony CCD TRV 128) were used to observe and record treeboa behavior. Treeboa encounters usually started at dusk $(\sim 1830 \mathrm{~h})$ and continued to $2355 \mathrm{~h}$. If necessary, additional surveys were made from $0010 \mathrm{~h}$ to $0500 \mathrm{~h}$.

\section{Results}

Dorsal ground colors recorded on the three islands were dark gray $(65 \%)$, dark orange $(30 \%)$, and yellow $(5 \%)$ on Camaleões and Baixão creeks, and dark gray (50\%), dark orange $(40 \%)$, and yellow (10\%) on Guirindó Creek. Minimum and maximum nocturnal boa perch heights varied according to high and low tides; some individuals were observed at $1.2-2.5 \mathrm{~m}$ on moonless nights, but perch heights were 2.3-7.0 m during the full moon. During the dry season, air temperature ranged between $29^{\circ} \mathrm{C}$ and $26^{\circ} \mathrm{C}$ between $1759 \mathrm{~h}$ and $2350 \mathrm{~h}$, and from $26^{\circ} \mathrm{C}$ to $24^{\circ} \mathrm{C}$ during 0030 $\mathrm{h}$ to $0445 \mathrm{~h}$. During the rainy season, air temperatures were between $28{ }^{\circ} \mathrm{C}$ and $26^{\circ} \mathrm{C}$ from $1759 \mathrm{~h}$ to $2359 \mathrm{~h}$, and between $26^{\circ} \mathrm{C}$ and $22^{\circ} \mathrm{C}$ during $0002 \mathrm{~h}$ and $0500 \mathrm{~h}$.

Activity.-In 1,320 encounters with $C$. hortulanus, approximately $30 \%$ were adults $(1,000-1,500 \mathrm{~mm} \mathrm{SVL})$, $50 \%$ subadults (800-1,000 mm SVL), 15\% juveniles (500-

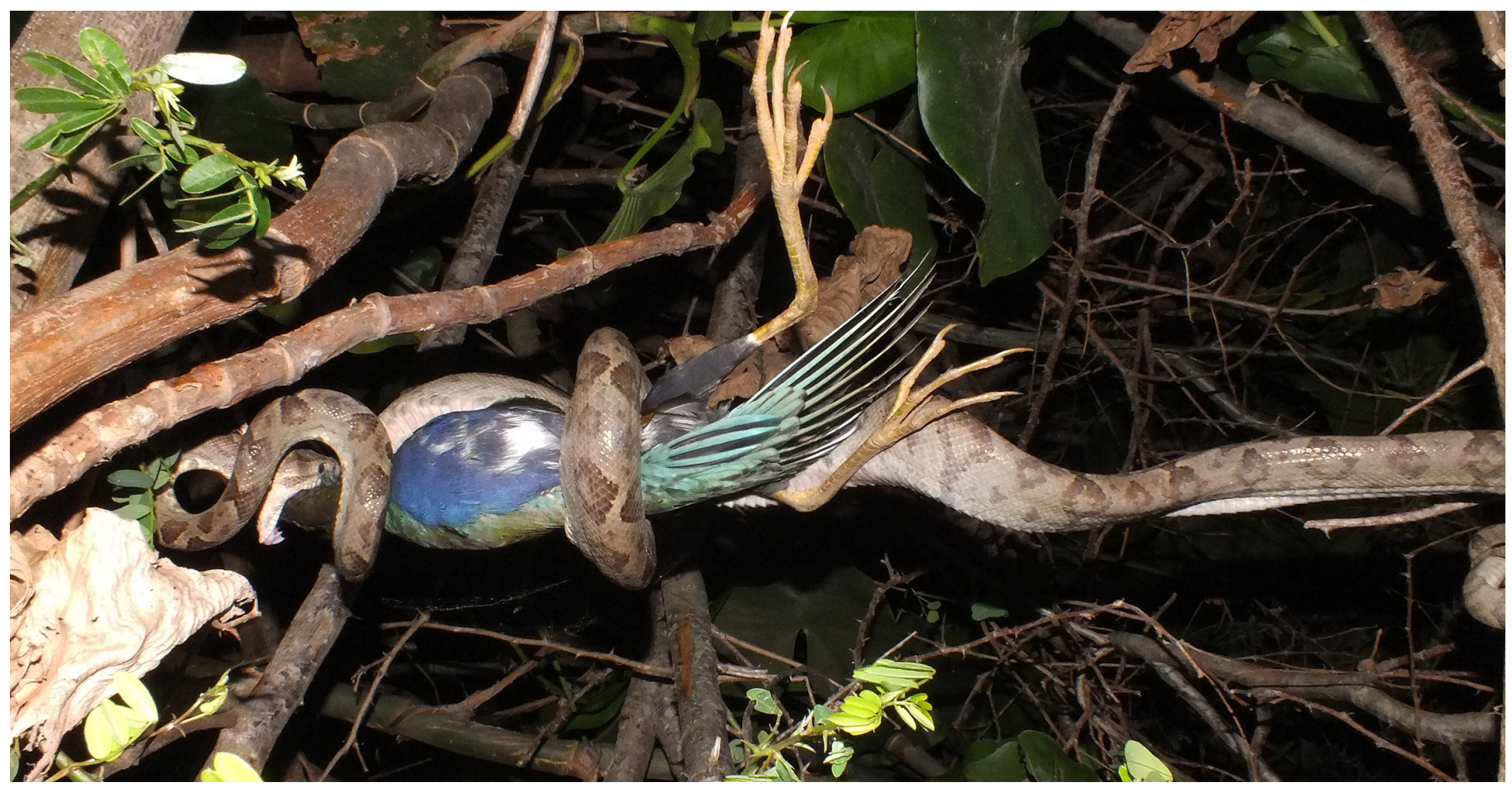

Fig. 5. Corallus hortulanus beginning to swallow a Purple Gallinule (Prophyrio martinica). 
$600 \mathrm{~mm} \mathrm{SVL}$ ), and 5\% neonates (270-350 mm SVL). Seven hundred ninety-five encounters occurred during moonless nights (new moon and first quarter), and three boas had captured prey: A Great Ani (Crotophaga major, da Costa Silva and Henderson 2010), a Purple Gallinule (Prophyrio martinica; da Costa Silva and Henderson 2013b; Fig. 5), and a Black Myotis (Myotis nigricans). Three other boas were observed stalking two different prey species, a Spiny Rat (Makalata sp.; da Costa Silva and Henderson 2012) and two Green Iguanas (Iguana iguana), without success. In addition, 48 adults and two neonates were coiled in resting postures with obvious bulges in their bodies indicating a recently ingested meal. Mating $C$. hortulanus were observed copulating in the afternoon during September and during the night of 27 June.

Three hundred encounters were recorded during moonlit nights (full moon and last quarter). Individual boas had captured a Great Kiskadee (Pitangus sulphuratus) and an Iguana (Iguana iguana; da Costa Silva et al. 2012) and two others were observed hanging by their tails with small portions of their heads submerged, possibly foraging for fish (da Costa Silva and Henderson 2010). Other boas were observed attempting (unsuccessfully) to capture a Spiny Rat (Makalata sp.), a Black Ani (Crotophaga ani), a Great Ani (Crotophaga major), a Tropical Screech-Owl (Megascops choliba), a Scaled Dove (Columbina squammata), and a Striated Heron (Butorides striata) on a nest along one of the creeks.
Most individuals were foraging (moving) in the shadows of trees and usually about $3 \mathrm{~m}$ above the ground. The high number of $C$. hortulanus restricting their activities to moonless nights is likely attributable to the risk of becoming prey (although they may remain visible to predators such as Barn Owls, Tyto alba; da Costa Silva and Henderson 2013a). During the rainy season, boa encounters decreased, although 53 observations were made during rainless intervals. When raining, $C$. hortulanus was frequently coiled under shelter provided by the leaves of the macrophyte Montrichardia linifera. On 26 April 2014, at $1830 \mathrm{~h}$ after 35 minutes of heavy rain, two boas were observed; at $1901 \mathrm{~h}$ our search was interrupted by heavy rain and lightning. At $1930 \mathrm{~h}$, the rain had stopped, the survey resumed, and another 13 treeboas were observed by $2030 \mathrm{~h}$ (for a total of ten adults $-1.30-1.50 \mathrm{~m}$ and five juveniles to $500 \mathrm{~mm}$ ); all were active.

An effort was made to determine how the boas spend daylight hours. Based on 225 encounters, boas remained coiled under shelter provided by vegetation along the creek. Only a mating couple was recorded as active during the day (da Costa Silva and Henderson 2014). Thirty-one boas were observed with noticeable bulges in their bodies, indicating that they had recently ingested a meal. Boas that had recently fed may spend up to ten days (depending on prey size) in a secluded site while digesting the meal, showing neither overt movements nor a necessity to drink. Fifty-five percent of

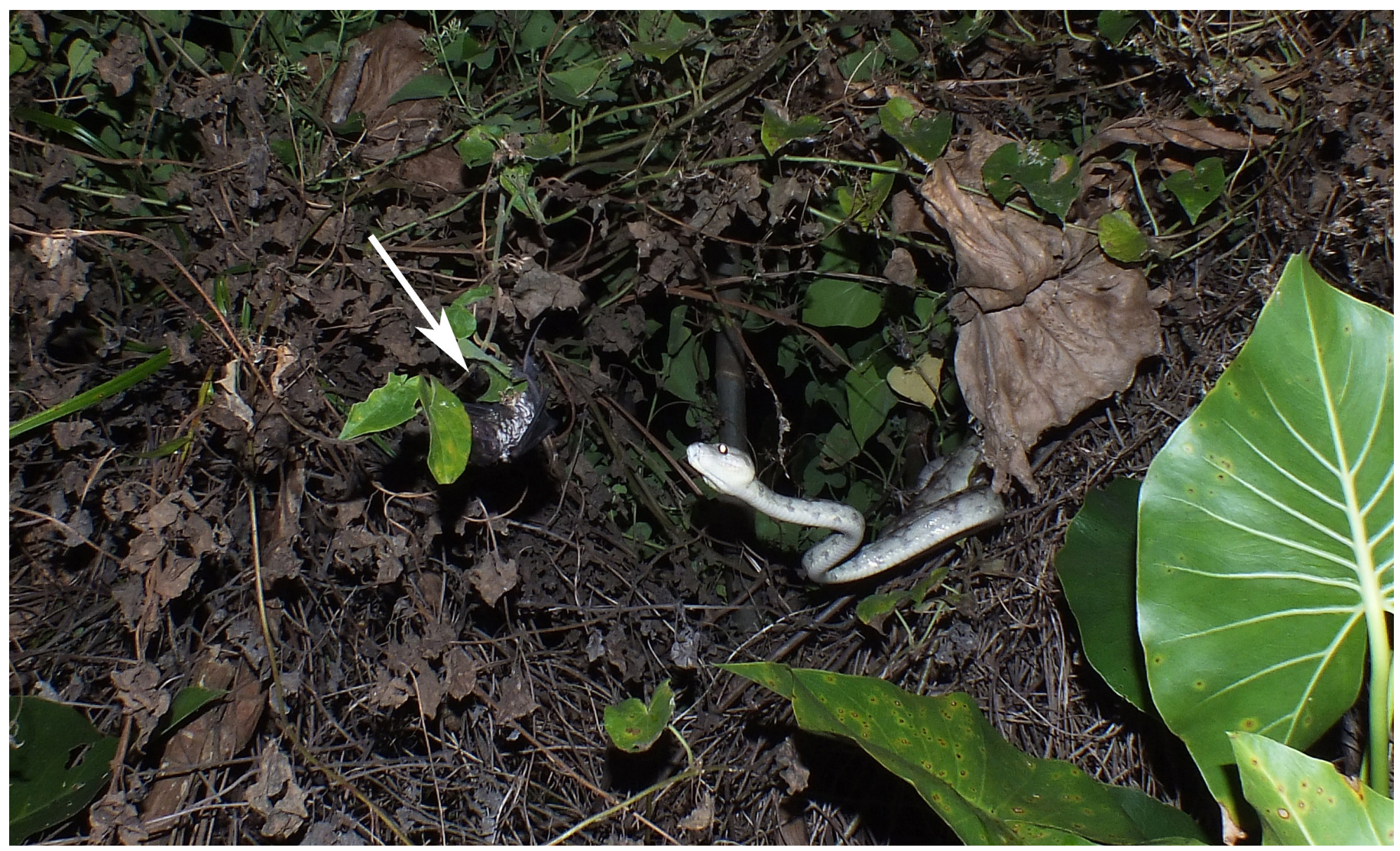

Fig. 6. Corallus hortulanus about to capture a bat (Myotis nigricans). 
subadult $C$. hortulanus were fully active, having captured or attempted to capture prey, compared to only $25 \%$ for adults, $15 \%$ for juveniles, and $5 \%$ for likely neonates on the three creeks.

The surveys also indicated that other species were more active or conspicuous along the three creeks during moonless nights. Fifty to 80 birds, represented by $8-13$ species, were observed during each of those surveys, including species that are known prey of $C$. hortulanus. The most frequently seen were: Great Ani (Crotophaga major), Black Ani (Crotophaga ani), Great Kingfisher (Ceryle torquata), Great Kiskadee (Pitangus sulphuratus), Wood Rail (Aramides mangle), Green Kingfisher (Chloroceryle americana), Purple Gallinule (Porphryrio martinica), Scaled Dove (Columbina squammata), Southern House Wren (Troglodytes musculus), Limpkin (Aramus guarauna), Barn Swallow (Hirundo rustica), Guira Cuckoo (Guira guira), Tropical Screech-Owl (Megascops choliba), and Striated Heron (Butorides striata). Additionally, between 90 and 150 adult and hatchling Green Iguanas (Iguana iguana) and ten rodents, mainly Spiny Rats (Makalata sp.), two Four-eyed Opossums (Philandersp.), and at least 25 bats were observed along the creeks. During moonlit nights, however, birds were not observed, except in "total alert" in deep forest shadows; this behavior continued until the moon was totally down.

Foraging and predation.-During an April 2013 survey at Camaleões creek, ten $C$. hortulanus of varying sizes were observed perched up to $7.0 \mathrm{~m}$ on branches of Pumpwood Trees (Cecropia sp.) The boas remained relatively close to flowers and fruits being visited by bats. On the night of 20 April 2014 at $1942 \mathrm{~h}$ along Laranjeira creek (3-5 m wide and $-1.0 \mathrm{~km}$ in length), we spotted the eye reflection of an adult $C$. hortulanus $(-1.5 \mathrm{~m})$ about to capture an adult bat (Myotis nigricans) with a body length of about $7 \mathrm{~cm}$ (Fig. 6). The boa was perched about $2.5 \mathrm{~m}$ above water level on a liana, and the bat was wrapped in two of the snake's coils. It remained in that position for five minutes and the bat was still alive. The boa had bitten the bat's back and at $1951 \mathrm{~h}$ it appeared to be dead. At 1952, the boa began searching for the bat's head, but at $1953 \mathrm{~h}$ the bat was released. At $1954 \mathrm{~h}$, the boa bit the bat's head a second time and, with the bat in its mouth, ascended toward the top of the bush. At $1956 \mathrm{~h}$, the bat was dropped and fell on dried leaves of $M$. linifera; it was immediately recovered and swallowing began at $1957 \mathrm{~h}$ (Fig. 7). The boa again ascended toward the top of the canopy, where it remained partially covered and by 1959 h only a small portion of the venter could be seen, but it was apparent that deglutition was nearly complete. At $2003 \mathrm{~h}$, the boa descended about $15 \mathrm{~cm}$ and coiled in a typical resting posture. By morning it had moved to another site.

Vegetation known as "restinga" or coastal forest occurs on the northern portion of Ilha Grande (Fig. 8). Much of this forest has been lost largely due to cutting for charcoal production, clearing for agriculture, and expanding sand dunes. The forest is comprised mainly of Carnaúba (Copernicia prunifera), Cashew (Anacardium occidentale), Angelica (Guettarda angelica), Imburana de Espinho (Commiphora leptophloeos), Jenipapo Bravo (Tocoyena sellowiana), Wild Passion Fruit (Passiflora subrotunda), Mucunã (Dioclea violacea), Café Bravo (Casearia guianensis), Mandacarú (Pilosocereus catingicola), Cereus jamacaru, and Guajiru (Chrysobalanus icaco) that grows on sandy soils. In a Tremembé Indian village called Saquim, restinga forest still survives in a preserved area. During the course of many years exploring restinga forest, the senior author finally encountered his first two $C$. hortulanus between $1830 \mathrm{~h}$ and $2350 \mathrm{~h}$ during a survey on 14 June 2014. An adult female with a total length of $-1.10 \mathrm{~m}$ was

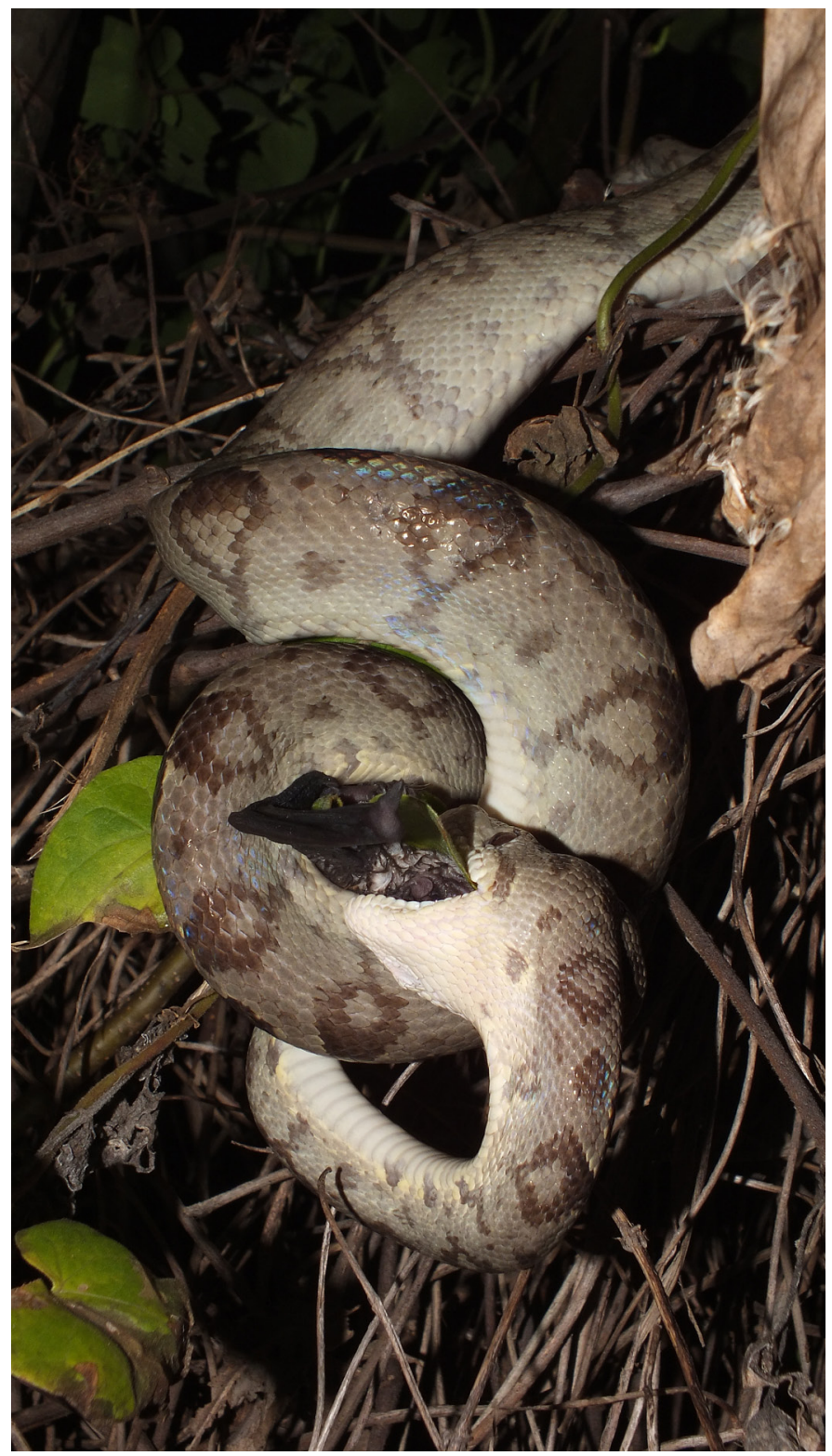

Fig. 7. The same snake as in Fig 6. with the captured bat. 


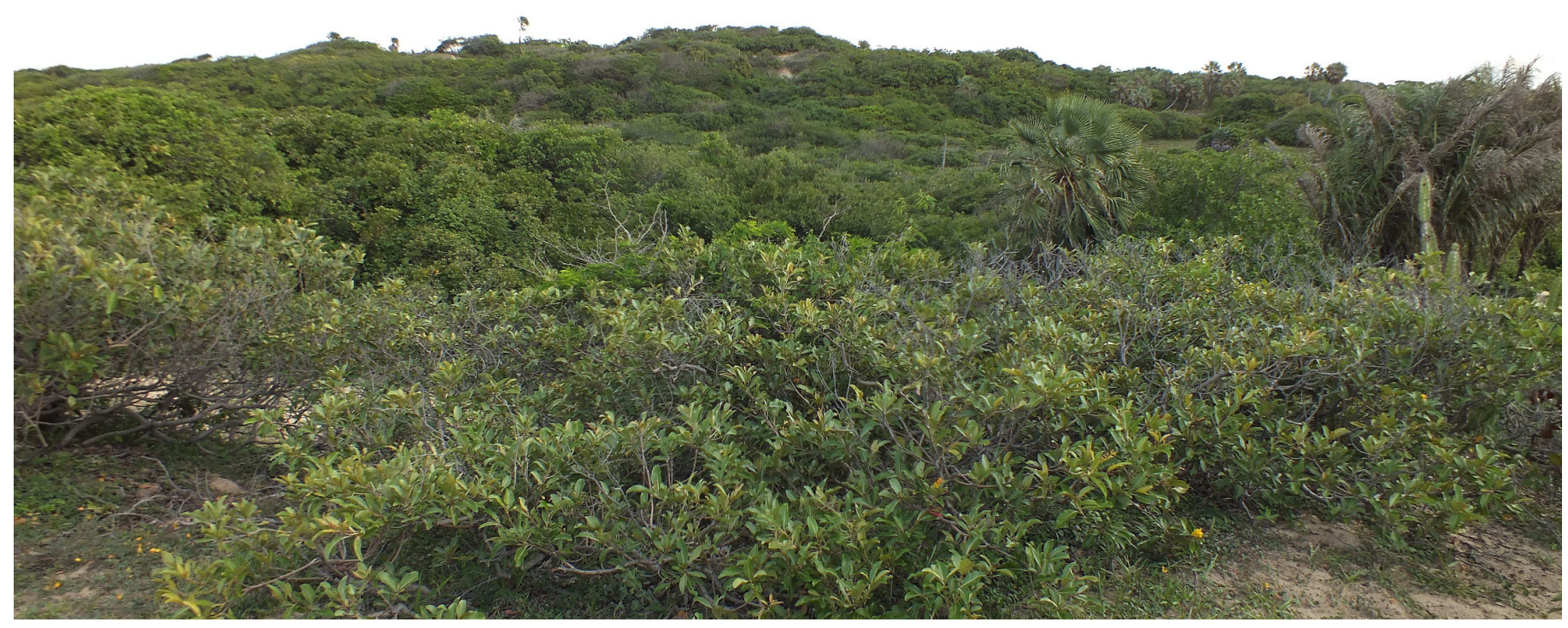

Fig. 8. Restinga forest on Ilha Grande.

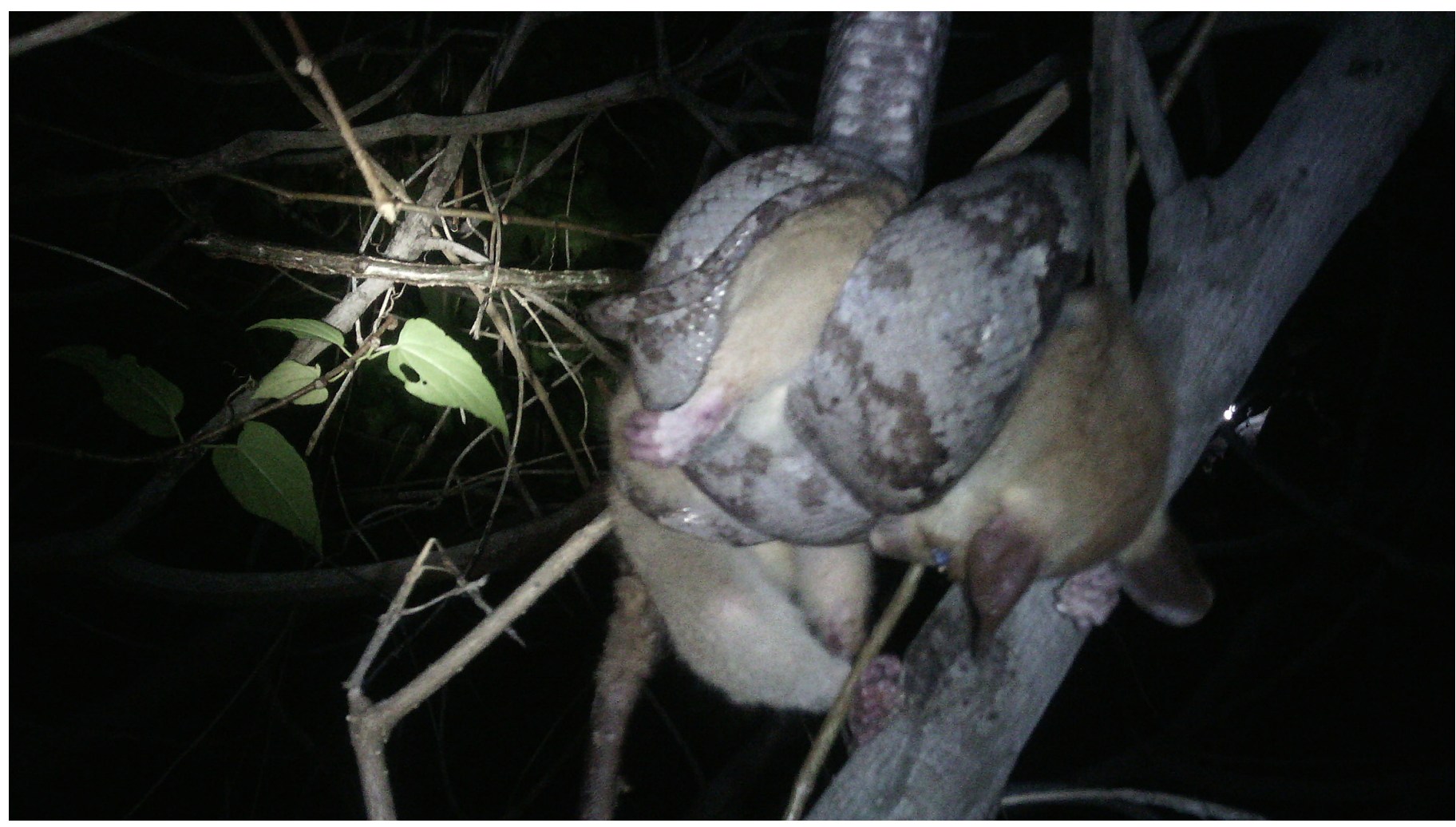

Fig. 9. Corallus hortulanus with a Bare-tailed Woolly Opossum (Caluromys philander).

seen migrating from the mangrove swamp to the restinga forest and another adult female ( $\sim 1.3 \mathrm{~m}$ total length) that had captured a female Bare-tailed Woolly Opossum (Caluromys philander). At $2025 \mathrm{~h}$, an unusual noise, sounding like the distress call of a bird, was heard coming from $20 \mathrm{~m}$ away. At 2033, the sound was eventually traced to the ground where the treeboa had three coils wrapped on the C. philander. Apparently the initial capture was made in a tree, but the ensuing struggle took them to the ground. The boa had difficulty killing the opossum as it was still alive, screaming and trying to escape, while the boa kept biting the base of the opossum's tail. The opossum had expelled a newborn from 
its marsupium (pouch) at $2056 \mathrm{~h}$. From $2100 \mathrm{~h}$ to $2120 \mathrm{~h}$, the boa's attempts to swallow the opossum were exasperated by ants that were apparently attracted to the prey; they bit the boa's lower jaw and it resorted to hitting its head on the ground several times in an attempt to dislodge the ants. At $2121 \mathrm{~h}$, with some difficulty, the boa began to ascend into a Cashew Tree. Finally, at $2136 \mathrm{~h}$, with the posterior half of its body suspended and the Caluromys grasped by two coils of its tail (Fig. 9), the boa reached a secure perch. The opossum's head was seized at $2149 \mathrm{~h}$, swallowing commenced, and was completed at $2202 \mathrm{~h}$. Between $2203 \mathrm{~h}$ and $2215 \mathrm{~h}$, the boa moved slowly among branches, and at $2220 \mathrm{~h}$, finally coiled under an umbrella of Carnaúba Palm fronds and leaves of Wild Passion Fruit. At 0930 h on the following morning, a search for the boa was unsuccessful.

The diet of Corallus hortulanus is the most taxonomically broad of any species of Corallus (Pizzatto et al. 2009; Henderson and Pauers 2012; Henderson, in press), including frogs, lizards, and a wide taxonomic range of birds and mammals (marsupials, rodents, bats). The reason for this trophic breadth is twofold: (1) C. hortulanus occurs in habitats that support great biodiversity, and (2) the species utilizes both ambush and active foraging strategies. By using both strategies, $C$. hortulanus encounters greater prey diversity than if only one or the other strategy is used. As an ambush forager, it has the potential to encounter nocturnally active species and, as an active forager, it has the potential to encounter prey that is nocturnally quiescent (e.g., sleeping and nesting birds).

\section{Acknowledgments}

The senior author dedicates this paper to Prof. Antônio Alvares Tavares. He also thanks José Roberto S.A. Leite, Prof. Roy Rosenstein (American University of Paris), Babara Cox, and Deuziene de Souza Silva for help during field expeditions. In addition, he is grateful to Ethielle Barroso de Andrade for producing the map of the study sites.

\section{References}

da Costa Silva, P. and R.W. Henderson. 2010. Observations on habitat, activity, foraging, and diet in the Amazon treeboa, Corallus hortulanus, on Batatas Island, Parnaíba Delta, Piauí, Brazil. Reptiles \& Amphibians 17:218-221.

da Costa Silva, P. and R.W. Henderson. 2012. Observations on foraging in the Amazon Treeboa (Corallus hortulanus). Herpetology Notes 5:531-532.

da Costa Silva, P. and R.W. Henderson. 2013a. Barn Owl (Tyto alba) predation on Corallus hortulanus (Squamata, Boidae). Herpetology Notes 6:35.

da Costa Silva, P. and R.W. Henderson. 2013b. Predation on a Purple Gallinule (Porphyrio martinica) by an Amazon Treeboa (Corallus hortulanus) on Ilha Grande, Piauí, Brazil. Herpetology Notes 6:233-234.

da Costa Silva, P. and R.W. Henderson. 2014. Mating behavior of Amazon Treeboas, Corallus hortulanus (Squamata: Boidae), on Batatas Island, Piauí, Brazil. Herpetology Notes 7:335-336.

da Costa Silva, P., R.W. Henderson, A. Alvares Tavares, S.C. Melo Araújo, and A. Guzzi. 2012. Observations on foraging and new prey records for the Amazon Treeboa (Corallus hortulanus, Squamata, Boidae). Reptiles \& Amphibians 19:187-190.

Henderson, R.W. In press. Natural History of Neotropical Treeboas (genus Corallus). Chimaira, Frankfurt-am-Main, Germany.

Henderson, R.W. and M.J. Pauers. 2012. On the diets of Neotropical treeboas (Squamata: Boidae: Corallus). South American Journal of Herpetology 7:172-180.

IBAMA.1998. Proteção e controle de ecossistemas costeiros. Manguezais da Baía de Babitonga/Instituto Brasileiro do Meio Ambiente e dos Recursos Naturais Renováveis. Coleção meio ambiente. Série estudos - pesca, 25. Brasília.

Pizzatto, L., O.A.V. Marques, and K. Facure. 2009. Food habits of Brazilian boid snakes: Overview and new data, with special reference to Corallus hortulanus. Amphibia-Reptilia 30:533-544. 